\title{
PENGARUH USIA KEHAMILAN TERHADAP GANGGUAN TIDUR PADA IBU HAMIL DI PBM ERNA PENIWATI DESA BALONG KECAMATAN BALONG PONOROGO
}

\author{
Ambika Kurnia Mustikawati \\ Akbid Harapan Mulya Ponorogo
}

\begin{abstract}
Pregnancy is a valuable thing, but also one of the great stresses for a woman both physically and mentally. Physical comfort disorders at each stage of gestational age vary due to interrupt the rest of pregnant women. This sleep disorder causes hypertension, exhaustion and disrupt activity. Interview results, 7 out of 10 pregnant women said experiencing sleep disorders. The purpose of this study was to analyze the effect of gestational age on sleep disturbance.

The research type is analytic with cross-sectional approach. Research location in PMB Erna Peniwati Desa Balong Kabupaten Ponorogo. The study was conducted on May 15 to June 10, 2018. Determination of the sample using a simple random sampling technique of 40. Dependent variable is sleep disturbance, while the independent variable is the age of pregnancy. Data collection techniques using questionnaires. Data analysis using Pearson test with the help of computer program SPSS 22,0 for windows.

The results showed that from 40 respondents, half of which were $20(50 \%)$ of pregnant women TM 3 had moderate sleep disorder and almost half that is as many as 12 (30\%) pregnant women TM 2 had mild sleep disorder. Result of calculation using Pearson statistic test with significant level 0,01 that is $p=0,000<\alpha$ 0,01 meaning Ho rejected and H1 accepted, so there is influence between pregnancy age with sleep disorder in pregnant woman in PMB Erna Peniwati with correlation coefficient 0,572 indicating closeness strong influence.

Different pregnancy rates affect sleep disturbance in each pregnant woman especially in the 3rd trimester pregnant women. It is expected to place the research to provide a solution for pregnant women so as to reduce the perceived sleep disturbance and respondents are expected to have a good way of dealing with sleep disorders for their health and the fetus and preparation for labor.
\end{abstract}

Keywords: Age of pregnancy, sleep disorders, pregnant women

\section{PENDAHULUAN}

Kehamilan tidak hanya masa sukacita yang besar, tetapi juga salah satu stress besar untuk seorang wanita baik secara fisik maupun mental. Bahkan pada wanita yang sehat, kehamilan dapat menimbulkan kesulitan tidur sehingga mempengaruhi kecemasan (M. Rauchfuss, 2011). Gangguan tidur pada ibu hamil pada masing-masing trimester berbeda-beda (Wahyuni dan Nida, 2010).

Kecemasan sering kali mengganggu tidur. Seseorang yang pikirannya dipenuhi dengan masalah pribadi dan merasa sulit untuk rileks saat akan memulai tidur. Kecemasan meningkatkan kadar norepinefrin dalam darah melalui stimulasi sistem saraf simpatis (Kozier et al, 2010).

Data statistik mencatat angka kematian ibu dalam kehamilan dan persalinan mencapai
515.000 jiwa setiap tahun, 99\% terjadi di Negara-negara berkembang. Di Negara miskin, sekitar 20-50\% kematian usia subur disebabkan hal yang berkaitan dengan kehamilan. Prevalensi tingkat kecemasan wanita hamil di Portugal (18,2\%), Bangladesh (29\%), Hongkong (54\%) dan Pakistan (70\%) (WHO, 2013).

Angka Kematian Ibu (AKI) di provinsi Jawa Timur sudah berada dibawah target Millenium Development Goals (MDGs) 2015 sebesar 102 kematian ibu per 100.000 kelahiran hidup. Secara rinci, data laporan kematian ibu Dinkes Kabupaten/ Kota melaporkan tahun 2011 sebesar 101,4 per 100.000 kelahiran hidup, pada tahun 2012 sebesar 97,43 per kelahiran hidup dan pada tahun 2013 sebesar 97,39 per 100.000 kelahiran hidup (SDKI, 2013). 
Berdasarkan studi pendahuluan yang dilakukan pada tanggal 1 sampai 3 Mei 2018 di PMB Erna Peniwati dari hasil wawancara dengan ibu hamil didapatkan 7 dari 10 orang mengatakan mengalami gangguan tidur selama kehamilan ini. Hal ini dapat dikatakan bahwa masih banyak ibu hamil yang mengalami gangguan tidur selama kehamilan.

Mendekati saat melahirkan, ibu hamil akan sulit mengatur posisi tidur. Gangguan ini dapat disebabkan karena semakin besar kehamilan sehingga diafragma akan tertekan ke atas dan mengganggu pernafasan. Pada ibu hamil disarankan untuk tidur dengan posisi miring kiri atau posisi yang membuat nyaman ibu hamil.

Pernafasan yang tidak baik pada ibu hamil akan berpengaruh pada berkurangnya pasokan oksigen pada otak sehingga dapat memengaruhi kualitas tidur (Emilia, 2010). Masalah lain yang umum selama kehamilan adalah nyeri ulu hati, atau bisa disebut sebagai penyakit gastroesophageal ref lux (GERD) yakni asam lambung berbalik kembali ke esofagus (Ayudhitya dan Tjuataja, 2014). Umumnya pada trimester III atau menjelang persalinan gangguan tidur mencapai puncaknya (Prasadja, 2009).

Ibu hamil yang memiliki kualitas tidur yang buruk dapat mengakibatkan beberapa komplikasi dalam kehamilan, seperti pada penelitian yang dilakukan oleh Okun (2011), yang menyatakan bahwa gangguan tidur yang terjadi pada ibu hamil dapat memperburuk respons inflamasi tubuh dan menyebabkan kelebihan produksi sitokin. Sitokin adalah molekul yang berhubungan dengan sel-sel kekebalan. Bila tubuh mengalami kelebihan sitokin maka dapat mengganggu arteri tulang belakang yang mengarah ke plasenta, menyebabkan penyakit pembuluh darah, dan kelahiran bayi prematur.

Tujuan dari penelitian ini adalah untuk menganalis seberapa besar pengaruh usia kehamilan terhadap gangguan tidur pada ibu hamil.

\section{TINJAUAN PUSTAKA \\ Konsep Gangguan Tidur}

Gangguan tidur atau somnipathy, adalah gangguan medis dari pola tidur seseorang. Beberapa gangguan tidur yang cukup serius untuk mengganggu fungsi fisik, mental, sosial dan emosional yang normal. Polisomnografi dan actigraphy yang tes umum diperintahkan untuk beberapa gangguan tidur. Gangguan tidur dapat disebabkan oleh berbagai masalah, dari gigi gerinda (bruxism) untuk teror malam. Ketika seseorang menderita kesulitan tidur dan atau tidur tanpa sebab yang jelas, itu disebut sebagai insomnia (Max, 2004).

Gangguan tidur secara luas diklasifikasikan menjadi dyssomnias, parasomnia, gangguan irama sirkadian tidur yang melibatkan waktu tidur, dan gangguan lainnya termasuk yang disebabkan oleh kondisi medis atau psikologis dan penyakit tidur. Beberapa gangguan tidur umum termasuk sleep apnea (berhenti bernapas selama tidur), narkolepsi dan hipersomnia (kantuk yang berlebihan pada waktu yang tidak), cataplexy (tiba-tiba kehilangan dan transien otot saat terjaga), dan penyakit tidur (gangguan siklus tidur karena infeksi). Gangguan lain termasuk sleepwalking, teror malam dan mengompol. Manajemen gangguan tidur yang sekunder untuk mental, kesehatan, atau gangguan penyalahgunaan zat harus fokus pada kondisi yang mendasarinya (Max, 2004).

Gangguan Tidur Yang Umum

Gangguan tidur yang paling umum termasuk:

a. Bruxism, tanpa sadar grinding atau mengepalkan gigi saat tidur

b. Catathrenia, mengerang nokturnal selama pernafasan berkepanjangan

c. Tertunda gangguan fase tidur (DSPD), ketidakmampuan untuk membangkitkan dan jatuh tertidur di kali diterima secara sosial tapi tidak ada masalah dengan pemeliharaan tidur, gangguan ritme sirkadian. Gangguan seperti lainnya yang canggih gangguan fase tidur (ASPD), non-24-jam gangguan tidur-bangun (non24) di terlihat atau pada orang buta, dan tidak teratur bangun tidur ritme, semua jauh lebih sedikit dibandingkan DSPD, serta situasional pergeseran gangguan kerja tidur. 
d. Sindrom Hypopnea, normal pernapasan dangkal atau laju pernapasan lambat saat tidur.

e. Hipersomnia idiopatik, primer, penyebab neurologis dari panjang-tidur, berbagi banyak kesamaan dengan narkolepsi.

f. Gangguan insomnia (susah tidur utama), kesulitan kronis pada jatuh tertidur dan / atau mempertahankan tidur bila tidak ada penyebab lain ditemukan gejala-gejala ini. Insomnia juga bisa komorbiditas dengan atau sekunder untuk gangguan lainnya.

g. Sindrom Kleine-Levin, gangguan langka yang ditandai dengan hipersomnia episodik gigih dan perubahan kognitif atau suasana hati

h. Narkolepsi, termasuk berlebihan kantuk di siang hari (EDS), sering berpuncak pada tertidur spontan tapi enggan pada waktu yang tidak. Juga sering dikaitkan dengan cataplexy, kelemahan mendadak pada otot motorik yang dapat mengakibatkan runtuhnya ke lantai.

i. Malam teror, Pavor nocturnus, gangguan teror tidur, kebangkitan mendadak dari tidur dengan perilaku yang konsisten dengan terror

j. Nokturia, kebutuhan sering untuk bangun dan buang air kecil di malam hari. Ini berbeda dari enuresis, atau mengompol, di mana orang tersebut tidak bangkit dari tidur, tapi kandung kemih tetap bermuara (Smith, 2011).

k. Parasomnia, mengganggu acara tidur yang berhubungan dengan melibatkan tindakan yang tidak pantas saat tidur, untuk berjalan misalnya tidur, malamteror dan catathrenia.

1. Periodik gangguan gerakan ekstremitas (PLMD), gerakan spontan tiba-tiba lengan dan / atau kaki selama tidur, misalnya menendang kaki. Juga dikenal sebagai nocturnal myoclonus. Lihat juga brengsek hypnic, yang tidak gangguan.

m. Cepat gerakan mata perilaku gangguan tidur (RBD), bertindak keluar mimpi kekerasan atau dramatis saat tidur REM, kadang-kadang melukai pasangan tidur atau diri (gangguan tidur REM atau RSD). n. Kaki gelisah sindrom (RLS), dorongan tak tertahankan untuk menggerakkan kaki. penderita RLS sering juga memiliki PLMD.

o. Pergeseran gangguan kerja tidur (SWSD), sebuah sirkadian gangguan ritme tidur situasional. (Jet lag sebelumnya dimasukkan sebagai gangguan ritme sirkadian tidur situasional, tetapi tidak muncul dalam DSM-5 (Manual Diagnostik dan Statistik Gangguan Mental).)

p. Sleep apnea, gangguan tidur apnea, obstruksi jalan napas saat tidur, menyebabkan kurangnya tidur nyenyak yang cukup, sering disertai dengan mendengkur. Bentuk lain dari sleep apnea adalah kurang umum. Ketika udara diblokir dari masuk ke paru-paru, individu tidak sadar terengah-engah untuk udara dan tidur terganggu. Berhenti bernapas dari setidaknya sepuluh detik, 30 kali dalam waktu tujuh jam tidur, mengklasifikasikan sebagai apnea. Bentuk lain dari apnea tidur termasuk sleep apnea sentral dan hipoventilasi tidur yang berhubungan.

q. Kelumpuhan tidur, ditandai dengan kelumpuhan sementara tubuh sesaat sebelum atau setelah tidur. kelumpuhan tidur bisa disertai dengan halusinasi visual, auditori atau taktil. Tidak gangguan kecuali parah. Sering dilihat sebagai bagian dari narkolepsi.

r. Sleepwalking atau berjalan sambil tidur, terlibat dalam kegiatan yang biasanya terkait dengan terjaga (seperti makan atau ganti), yang mungkin termasuk berjalan, tanpa sepengetahuan sadar subjek

s. Somniphobia, salah satu penyebab kurang tidur, ketakutan / takut tidur atau tidur. Tanda-tanda penyakit ini termasuk kecemasan dan panik serangan sebelum dan selama upaya untuk tidur.

\section{Konsep Kehamilan}

Hasil dari multi studi berbasis komunitas etnis besar di Amsterdam yang melibatkan 7740 wanita hamil mengungkapkan bahwa kehamilan kecemasan terkait dengan hasil kerja yang merugikan seperti prematur dan 
berat badan lahir rendah hal ini dipengaruhi oleh gangguan tidur pada ibu hamil (Dijk, et al., 2013). Perbedaan ini terutama menyangkut karena hasil kelahiran prematur secara lebih risiko kesehatan bagi bayi dan sering membawa biaya emosional dan finansial yang luar biasa untuk keluarga (Hamilton et al., 2013).

Adapun karakteristik ibu hamil yang mempengaruhi kecemasan dan hal ini mempengaruhi gangguan tidur antara lain:

a. Umur

WHO memberikan rekomendasi umur yang dianggap paling aman menjalani kehamilan dan persalinan adalah 20-35 tahun. Di rentang usia ini kondisi fisik wanita dalam keadaan prima. Rahim sudah mampu memberi perlindungan, mental pun siap untuk merawat dan menjaga kehamilannya secara hati-hati.

Kehamilan di umur kurang dari 20 tahun bisa menimbulkan masalah, karena kondisi fisik belum $100 \%$ siap. Beberapa resiko yang bisa terjadi pada kehamilan di umur ini adalah kecenderungan naiknya tekanan darah dan pertumbuhan janin terhambat. Di luar urusan kehamilan dan persalinan, resiko kanker leher rahim pun meningkat akibat hubungan seks dan melahirkan. Sedangkan setelah umur 35 tahun, sebagian wanita digolongkan pada kehamilan beresiko tinggi terhadap kelainan bawaan dan adanya penyulit pada waktu persalinan. Di kurun umur ini, angka kematian ibu melahirkan dan bayi meningkat (Tobing, 2007).

b. Paritas

Paritas adalah banyaknya kelahiran hidup yang dipunyai oleh seorang wanita (BKKBN, 2006). Primipara adalah wanita yang telah melahirkan seorang anak, yang cukup besar untuk hidup di dunia luar (Varney, 2006). Sedangkan multipara adalah wanita yang telah melahirkan seorang anak lebih dari satu kali (Prawirohardjo, 2009).

Ibu akan cenderung merasa cemas dengan kehamilannya, merasa gelisah, dan takut menghadapi persalinan, mengingat ketidaktahuan menjadi faktor penunjang terjadinya kecemasan. Bagi primipara, kehamilan yang dialaminya merupakan pengalaman pertama kali, sehingga trimester III dirasakan semakin mencemaskan karena semakin dekat dengan proses persalinan. Ibu akan cenderung merasa cemas dengan kehamilannya, merasa gelisah, dan takut menghadapi persalinan, mengingat ketidaktahuan menjadi faktor penunjang terjadinya kecemasan. Sedangkan ibu yang pernah hamil sebelumnya (multigravida), mungkin kecemasan berhubungan dengan pengalaman masa lalu yang pernah dialaminya (Zamriati, 2013).

c. Usia Kehamilan

Perubahan psikologis pada trimester pertama, setelah konsepsi kadar hormon progesterone dan estrogen dalam tubuh akan meningkat dan ini menyebabkan timbulnya mual dan muntah pada pagi hari, lemah, lelah dan membesarnya payudara. Pada trimester pertama seringkali timbul kecemasan dan rasa kebahagiaan bercampur keraguan dengan kehamilannya antara ya atau tidak, terjadi fluktuasi emosi sehingga beresiko tinggi untuk terjadinya pertengkaran atau rasa tidak nyaman, adanya perubahan hormonal, dan morning sickness. Diperkirakan ada $80 \%$ ibu-ibu mengalami perubahan psikologis, seperti rasa kecewa, sikap penolakan, cemas dan rasa sedih (Rukiyah, 2011).

Reaksi psikologis pada trimester kedua, ibu hamil tampak lebih tenang dan mulai dapat beradaptasi, perhatian mulai beralih pada perubahan bentuk tubuh, kehidupan seksual, keluarga, dan hubungan batiniah dengan bayi yang dikandungnya, serta peningkatan kebutuhan untuk dekat dengan figur ibu, melihat, dan meniru peran ibu. Ibu seringkali merasa khawatir atau takut kalau bayi yang akan dilahirkannya tidak normal. Kebanyakan ibu juga akan bersikap melindungi bayinya dan menghindari orang atau benda yang dianggap membahayakan bayi. Ibu mulai merasa takut atas rasa sakit dan bahaya fisik yang akan timbul pada saat melahirkan (Sulistyawati, 2012). 
Perubahan psikologis pada trimester ketiga, perubahan psikologis ibu hamil periode trimester terkesan lebih kompleks dan lebih meningkat kembali dari trimester sebelumnya. Hal ini dikarenakan kondisi kehamilan semakin membesar. Kondisi itu tidak jarang memunculkan masalah seperti posisi tidur yang kurang nyaman dan mudah terserang rasa lelah atau kehidupan emosi yang fluktuatif. Perubahan emosional trimester III terutama pada bulan-bulan terakhir kehamilan biasanya gembira bercampur takut karena kehamilan telah mendekati persalinan. Rasa kekhawatirannya terlihat menjelang melahirkan, apakah bayi lahir sehat dan tugas-tugas apa yang dilakukan setelah kelahiran (Sulistyawati, 2012).

d. Status Kesehatan

Pemeliharaan dan pelayanan kesehatan dapat terjamin. Seorang ibu dapat mengetahui semua informasi kesehatan mengenai dirinya dan bayi yang ada dalam kandungannya, sehingga dapat menjalani kehamilan yang aman dan menyenangkan, serta mencegah timbulnya kecemasan.

e. Dukungan Sosial (Keluarga)

Dukungan sosial merupakan bantuan atau dukungan yang diterima individu dari orang-orang tertentu dalam kehidupannya dan berada dalam lingkungan sosial tertentu seperti suami, orangtua, mertua, teman atau tetangga yang membuat penerima merasa diperhatikan, dihargai dan dicintai sedang-kan untuk orang yang menerima dukungan sosial memahami makna dukungan sosial yang diberikan oleh orang lain.

Dukungan keluarga terutama dari suami merupakan faktor utama yang berpengaruh terhadap terjadinya kecemasan pada ibu hamil dalam menghadapi masa kehamilan sampai persalinan. Beberapa bentuk dukungan suami yang sangat dibutuhkan oleh ibu hamil antara lain, pelayanan yang baik, menyediakan transportasi atau dana untuk biaya konsultasi, dan menemani berkonsultasi ke dokter ataupun bidan sehingga suami dapat mengenali tanda-tanda komplikasi kehamilan dan juga kebutuhan ibu hamil (Asrinah, 2010).

Menurut National Sleep Foundation (2007) dalam Rezaei (2015), perempuan hamil yang mengalami beberapa bentuk gangguan tidur mencapai $79 \%$. Sebanyak $72 \%$ dari ibu hamil akan mengalami frekuensi terbangun lebih sering pada malam hari. Umumnya kebutuhan tidur orang dewasa yakni selama 7-8 jam, namun untuk ibu hamil bisa mencapai 10 jam. Hal ini tergantung pada umur saat ibu hamil dan stamina yang dirasakan ibu. Kualitas tidur yang baik akan menjaga kesehatan ibu selama hamil serta memberikan cukup energi saat persalinan. Penelitian yang dilakukan oleh Komalasari et al (2012), di Jatinangor mengenai kualitas tidur ibu hamil trimester III didapatkan hasil bahwa sebanyak $72,2 \%$ dari 54 ibu hamil yang diteliti memiliki kualitas tidur yang buruk dan terdapat hubungan yang bermakna antara tingkat kecemasan dengan kualitas tidur ibu hamil. Sejalan dengan penelitian yang dilakukan Komalasari et al (2012), penelitian yang dilakukan oleh Andari (2013), di Medan juga menunjukkan bahwa 63\% dari 41 ibu hamil mempunyai kualitas tidur yang buruk karena perubahan fisiologis dan psikologis yang dialami ibu ketika hamil.

Data menurut Profil Kesehatan Jawa Timur tahun 2014 didapatkan hasil masih banyak komplikasi dalam kehamilan. Komplikasi kehamilan tertinggi di Jawa Timur adalah di Kota Surabaya (Dinkes Provinsi Jawa Timur, 2014) yang mencapai 9513 kasus. Tahun 2015 diperkirakan ibu hamil yang mengalami komplikasi sebesar 6526 orang.

Wilayah di Kota Surabaya yang memiliki komplikasi ibu hamil tertinggi terletak di Puskesmas Gading yakni terjadi komplikasi kehamilan sebesar 268 kasus (Dinkes Surabaya, 2015). Puskesmas Gading melingkupi 3 kelurahan yakni Kelurahan Gading, Kelurahan Kapas Madya baru, dan Kelurahan Rangkah. Dari data tahun 2016 dari bulan Januari sampai November komplikasi yang terjadi pada ibu hamil 
tertinggi yakni di Kelurahan Gading yakni untuk kasus hipertensi dalam kehamilan sebanyak 23 kasus dalam Kehamilan. Akibat dari komplikasi-komplikasi tersebut 14 kasus diantaranya merupakan partus prematur. Tahun 2016 dari bulan Januari sampai November di Puskesmas Gading juga terdapat Angka Kematian Ibu (AKI) sebanyak 1 kasus yang terdapat di Kelurahan Gading.

\section{METODE PENELITIAN}

Penelitian ini termasuk penelitian ex post facto. Lokasi penelitian di PMB Erna Peniwati. Penelitian ini dilaksanakan pada 15 Mei-10 Juni 2018. Penentuan sampel menggunakan teknik simple random sampling yaitu sebanyak 36 . Teknik pengumpulan data menggunakan kuisioner.

Definisi operasional dalam penelitian ini yaitu:

a. Usia Kehamilan

Usia kehamilan adalah ukuran lama waktu janin berada di dalam rahim (minggu) yang dibagi menjadi 3 yaitu trimester 1 usia kehamilan 0-12 minggu, trimester 2 yaitu usia kehamilan 13-24 minggu, trimester 3 yaitu usia kehamilan 25-40 minggu. Usia kehamilan menggunakan alat ukur kuesioner. Kuesioner dengan 1 pertanyaan, dinilai dengan skala interval: diberi nilai 1 apabila Trimester 1 (0-12 minggu), nilai 2 apabila Trimester 2 (13-24 minggu), nilai 3 Trimester 3 (25-36 minggu).

b. Gangguan Tidur

Gangguan tidur lebih banyak berkaitan dengan masalah psikis, seperti rasa kekhawatiran (cemas). Sulit tidur sering terjadi pada ibu yang baru pertama kali hamil (primigravida) dan menjelang kelahiran (trimestrer III).Gangguan tidur menggunakan alat ukur kuesioner PSQI (Pittsburgh Sleep Quality Index). Komponen dari kualitas tidur ini merujuk pada pertanyaan nomor $5 \mathrm{~b}-5 \mathrm{j}$ dalam PSQI, yang terdiri dari halhal yang dapat menyebabkan gangguan tidur. Tiap item memiliki skor 0-3, dengan 0 berarti tidak pernah sama sekali dan 3 berarti sangat sering. Skor kemudian dijumlahkan sehingga dapat diperoleh skor gangguan tidur. Di nilai dengan skala ordinal:

1. Skor gangguan tidur 0:0 (tidak ada gangguan tidur)

2. Skor gangguan tidur 1-9 : 1 (gangguan tidur ringan)

3. Skor gangguan tidur 10-18: 2 (gangguan tidur sedang)

4. Skor gangguan tidur 19-27: 3 (gangguan tidur berat)

Kecemasan kehamilan merupakan keadaan emosi negatif yang terkait dengan kekhawatiran tentang "kesehatan dan kesejahteraan seseorang bayi, siapa yang membantu melahirkan, rumah sakit dan pengalaman perawatan kesehatan (termasuk seseorang kesehatan sendiri dan kelangsungan hidup pada kehamilan), kelahiran dan postpartum, dan peran orang tua atau ibu. Kecemasan menggunakan alat ukur HARS (Hamilton Anxiety Rating Scale). Skala HARS terdapat 14 syptoms yang nampak pada individu yang mengalami kecemasan. Dinilai dengan skala likert: diberi nilai $0=$ tidak ada gejala sama sekali, 1 = Satu dari gejala yang ada, 2 =sedang/ separuh dari gejala yang ada, $3=$ berat/lebih dari setengah gejala yang ada, 4 = sangat berat semua gejala ada. Penentuan derajat kecemasan dengan cara menjumlah nilai skor dan item 1-14 dengan hasil:

1) Skor kurang dari $6=$ tidak ada kecemasan

2) Skor $7-14=$ kecemasan ringan

3) Skor $15-27=$ kecemasan sedang

4) Skor lebih dari $27=$ kecemasan berat Setelah data terkumpul kemudian dilakukan pengolahan data dengan Editing, Coding, Scoring, Tabulasi data. Data diolah dengan tabulasi silang dan analisis Pearson dengan bantuan program komputer yaitu SPSS 22.0 for Windows pada taraf signifikan 0,01 . Jika $\mathrm{p}<\alpha 0.01 \mathrm{H} 0$ ditolak dan jika $\mathrm{p}>\alpha 0.01 \mathrm{H} 0$ diterima.

\section{HASIL PENELITIAN}

1. Usia Kehamilan Ibu Hamil

Tabel 1

Distribusi Frekuensi Usia Kehamilan Ibu Hamil di PMB Erna Peniwati Tahun 2018 


\begin{tabular}{lcc}
\hline Kriteria & Frekuensi & Persen $(\%)$ \\
\hline Trimester 1 & 8 & 20.0 \\
\hline Trimester 2 & 12 & 30.0 \\
\hline Trimester 3 & 20 & 50.0 \\
\hline Total & 40 & 100.0 \\
\hline
\end{tabular}

Sumber : Kuesioner

Berdasarkan tabel 1 diatas menunjukkan bahwa setengahnya yaitu sebanyak 20 responden $(50 \%)$ merupakan trimester 3, hampir setengahnya yaitu sebanyak 12 responden (30\%) merupakan trimester 2 dan sebagian kecil yaitu 8 responden $(20 \%)$ merupakan trimester 1 .

2. Gangguan Tidur Ibu Hamil

Tabel 2

Distribusi Frekuensi Gangguan Tidur Ibu Hamil di PMB Erna Peniwati Tahun 2018

\begin{tabular}{ccc}
\hline Kriteria & Frekuensi & $\begin{array}{c}\text { Persen } \\
(\%)\end{array}$ \\
\hline Tidak ada gangguan tidur & 9 & 22.5 \\
\hline Gangguan tidur ringan & 19 & 47.5 \\
\hline Gangguan tidur sedang & 10 & 25.0 \\
\hline Gangguan tidur berat & 2 & 5 \\
\hline Total & 40 & 100.0 \\
\hline
\end{tabular}

Sumber : Kuesioner

Berdasarkan tabel diatas menunjukkan bahwa hampir setengahnya responden yaitu sebanyak 19 (47,5\%) mengalami gangguan tidur ringan, hampir setengahnya responden yaitu sebanyak 10 $(25 \%)$ mengalami gangguan tidur sedang, sebagian kecil responden yaitu sebanyak 9 $(22,5 \%)$ mengalami gangguan tidur sedang dan sebagian kecil responden 2 (5\%) mengalami gangguan tidur berat.

3. Tabulasi Silang Usia Kehamilan Terhadap Gangguan Tidur Pada Ibu Hamil

Tabel 3 Tabulasi Silang Usia Kehamilan Terhadap Gangguan Tidur Pada Ibu Hamil di PMB Erna Peniwati Tahun 2018

\begin{tabular}{ccccccc}
\hline Usia & \multicolumn{3}{c}{ Gangguan Tidur } & Total & $\%$ \\
\cline { 2 - 6 } Kehamilan & $\begin{array}{c}\text { Tidak } \\
\text { ada }\end{array}$ & Ringan & Sedang & Berat & & \\
\hline TM 1 & 4 & 4 & 0 & 0 & 8 & 20 \\
\hline TM 2 & 4 & 7 & 1 & 0 & 12 & 30 \\
\hline TM 3 & 1 & 8 & 9 & 2 & 20 & 50 \\
\hline Total & 9 & 19 & 10 & 2 & 40 & 100 \\
\hline
\end{tabular}

Sumber : Kuesioner

Berdasarkan tabel 3 menunjukkan bahwa dari 40 responden, setengahnya yaitu sebanyak $20(50 \%)$ ibu hamil TM 3 mengalami gangguan tidur sedang dan hampir setengahnya yaitu sebanyak 12 (30\%) ibu hamil TM 2 mengalami gangguan tidur ringan.
4. Uji Statistik Pengaruh Usia Kehamilan Terhadap Gangguan Tidur Pada Ibu Hamil Tabel 4

Pengaruh usia kehamilan terhadap gangguan tidur pada Ibu Hamil di PMB Erna Peniwati

\begin{tabular}{|c|c|c|c|}
\hline \multicolumn{4}{|c|}{ Correlations } \\
\hline & & UK & G_Tidur \\
\hline \multirow[t]{3}{*}{ UK } & Pearson Correlation & 1 &, 572 \\
\hline & Sig. (2-tailed) & &, 000 \\
\hline & $\mathrm{N}$ & 40 & 40 \\
\hline \multirow[t]{3}{*}{ G_Tidur } & Pearson Correlation &, $572^{* *}$ & 1 \\
\hline & Sig. (2-tailed) & ,000 & \\
\hline & $\mathrm{N}$ & 40 & 40 \\
\hline
\end{tabular}

Berdasarkan tabel 4 diatas dengan hasil perhitungan menggunakan uji statistik Pearson dengan taraf signifikan 0,01 yaitu $\mathrm{p}=0,000<\alpha 0,01$ artinya Ho ditolak dan H1 diterima, sehingga ada pengaruh antara usia kehamilan dengan gangguan tidur pada ibu hamil di PMB Erna Peniwati dengan koefisien korelasi 0,572 yang menunjukkan keeratan pengaruh kuat.

\section{PEMBAHASAN}

Hasil perhitungan menggunakan uji statistik Pearson dengan taraf signifikan 0,01 yaitu $\mathrm{p}=0,000<\alpha 0,01$ artinya Ho ditolak dan H1 diterima, sehingga ada pengaruh antara usia kehamilan dengan gangguan tidur pada ibu hamil di PMB Erna Peniwati dengan koefisien korelasi 0,572 yang menunjukkan keeratan pengaruh kuat.

Berdasarkan hasil tabulasi silang pada tabel 3 menunjukkan bahwa dari 40 responden, setengahnya yaitu sebanyak 20 (50\%) ibu hamil TM 3 mengalami gangguan tidur sedang dan hampir setengahnya yaitu sebanyak 12 (30\%) ibu hamil TM 2 mengalami gangguan tidur ringan.

Ibu hamil memerlukan sekitar delapan jam untuk tidur di malam hari, selain itu tidur siang juga dibutuhkan oleh ibu hamil. Ibu hamil terutama bila sudah memasuki Trimester III memerlukan istirahat seperti duduk dan bersantai di sela-sela melakukan kegiatan rutinnya. Ketika memasuki trimester III semakin banyak keluhan-keluhan yang 
dirasakan ibu sehingga akan mengganggu istirahat dan tidur (Siswosuhardjo, 2010).

Berdasarkan tabel 1 diatas menunjukkan bahwa setengahnya yaitu sebanyak 20 responden (50\%) merupakan trimester 3 dan mengalami gangguan tidur sedang. Hal ini sejalan dengan penelitian yang dilakukan oleh Tsai et al (2011), pada 30 ibu hamil yang meneliti tentang kualitas tidur ibu hamil trimester III di Taiwan didapatkan $50 \%$ dari ibu hamil mempunyai skor PSQI lebih besar dari 5. Skor kurang dari 5 menunjukkan ibu hamil memiliki kualitas tidur yang buruk.

Penelitian yang dilakukan oleh Mendell et al (2015), pada 2427 responden menyatakan bahwa $76 \%$ diantaranya mengalami kualitas tidur yang buruk. Seluruh responden menyatakan sering terbangun di malam hari, sebanyak $78 \%$ menyatakan tidur siang dan $57 \%$ menunjukkan adanya gejala insomnia. Gangguan tidur yang terjadi dapat berupa gangguan nafas, Restless Legs Syndrom atau gangguan saraf pada kaki, buang air kecil dan kesulitan untuk menemukan posisi tidur yang nyaman.

Penelitian yang dilakukan Lee (2004) menyatakan wanita yang tidur kurang dari6 jam per malam memiliki kemungkinan menjalani operasi caesar 4,5 kali lebih besar. Ibu hamil disarankan tidur 8 jam per malam. Sebanyak 52,8\% ibu hamil trimester III yang menjadi responden dalam penelitian ini mengaku tidur kurang lebih 5 jam per malam. Ibu hamil mengaku sering bangun di malam hari, hal ini berarti masih kurangnya jam tidur ibu hamil pada malam hari.

\section{KESIMPULAN DAN SARAN}

Ibu hamil disarankan tidur 8 jam per malam untuk kesehatan dirinya dan juga janinnya. Ibu hamil yang memiliki kualitas tidur yang buruk dapat mengakibatkan beberapa komplikasi dalam kehamilan, seperti pada penelitian yang dilakukan oleh Okun (2011), yang menyatakan bahwa gangguan tidur yang terjadi pada ibu hamil dapat memperburuk respons inflamasi tubuh dan menyebabkan kelebihan produksi sitokin. Sitokin adalah molekul yang berhubungan dengan sel-sel kekebalan. Bila tubuh mengalami kelebihan sitokin maka dapat mengganggu arteri tulang belakang yang mengarah ke plasenta, menyebabkan penyakit pembuluh darah, dan kelahiran bayi prematur.

Dari penelitian ini diharapkan bisa dijadikan sebagai masukan untuk tenaga kesehatan khususnya bidan maupun staf Kesehatan Ibu dan Anak (KIA) untuk meningkatkan peran serta dukungan suami dalam pemantauan kesehatan ibu hamil. Petugas kesehatan juga selalu memonitoring kesehatan ibu hamil pada saat pemeriksaan kesehatan ibu hamil atau Antenatal Care (ANC). Pemeriksaan ini termasuk mengenai adanya gangguan tidur pada ibu hamil khususnya pada trimester III dan penyebab ibu hamil mengalami gangguan tidur seperti gangguan kenyamanan fisik maupun adanya penyakit yang diderita ibu hamil.

Adanya hasil penelitian ini dapat menjadi masukan bagi peneliti selanjutnya untuk meneliti faktor yang berhubungan dengan gangguan tidur lainnya pada ibu hamil.

\section{DAFTAR PUSTAKA}

Ada, Y. (2008). Kebisingan, Pencahayaan, dan Getaran di Tempat Kerja. Mitra No. 3 Tahun XIV Desember 2008.

Andari, P., 2013. Kualitas Tidur dan Pola Tidur Ibu Hamil Trimester III yang Datang Memeriksakan Kehamilan di klinik Mariati Kecamatan Medan Marelan Tahun 2013.Skripsi. Universitas Sumatera Utara

Bobak, I. M., et al. ( 2005). Maternity Nursing. Ed. 4 Mosby Year Book.

Cole L, Kershaw V, Yonkers A, Lin H, Ickovics J. (2014). Pregnancy Specific Stress, Preterm Birth And Gestasional Age Among High Risk Young Women, Health Psychol. NIH Public Access33 (9): 1033-1045. doi: 10.1037/a0034586

Dinas Kesehatan Kota Surabaya. Profil Kesehatan Kota Surabaya. 2015.

Dinas Kesehatan provinsi Jawa Timur. Profil Kesehatan Jawa Timur. 2014

Dunkel SC, Lobel M. (2011) . Pregnancy And Birth: A Multilevel Analysis Of Stress And 
Birth Weight. In: Revenson, T.; Baum, A.; Singer, J., editors. Handbook of health psychology 2. Lawrence Erlbaum; Mahwah, NJ: 2011. p. 427-453.

Huliana,M.2007.Panduan Menghadapi Kehamilan Sehat.Jakarta.Puspa Swara

Iriana, D.K. 2013. Hubungan Kecemasan dan gangguan kenyamanan Fisik terhadap kualitas tidur ibu hamil di Puskesmas Helvetia medan

Kizılırmak A, Timur S, and Kartal B, (2012). Insomnia in Pregnancy and Factors Related to Insomnia. ScientificWorldJournal. 2012; 2012: 197093. Published online 2012 Apr 24. doi: 10.1100/2012/197093 PMCID: PMC3349327

Kozier, et al. (2010). Buku Ajar Fundamental Keperawatan: Konsep, Proses Dan Praktik. Jakarta. EGC

Madhavanprabhakaran GK and MS D'Souza, KS. (2015). Prevalence Of Pregnancy Anxiety And Associated Factors. International Journal Of Africa Nursing Sciences Volume 3, 2015, Pages 1-7

M. Rauchfuss, B. (2011). Maier Biopsychosocial Predictors Of Preterm Delivery. Journal of Perinatal Medicine, 39 (5) (2011), pp. 515-521

Murti, B. (2013). Desain Dan Ukuran Sampel Untuk Penelitian Kuantitatif Dan Kualitatif Di Bidang Kesehatan.
Yogyakarta: Gajah Mada University Press.

(2011). Validitas Dan Reliabilitas Pengukuran. Internet available from fk.uns.ac.id/index.php/download/file/61 Diakses pada tanggal 18 November 2015.

Okun, M. 2011. Poor Sleep Quality is Associated with Preterm Birth.J. Sleep. Vol 34. Nomor 11.. Halaman 1493-1498

Rukiyah, et al. (2011). Asuhan Kebidanan I (Kehamilan). Jakarta: CV. Trans Info Media

SDKI, (2013). Angka Kematian Ibu Sreesupriya. 2014. A Study on Sleep Disturbances Among Antenatal Women Attending A Tertiary Care Hospital, in Chennai, Tamilnadu. Indian Journal of Applied Research. Vol 4. Nomor 10. Halaman 426-428

Sulistyawati, Ari.2012.Asuhan Kebidanan pada Masa Kehamilan.Jakarta: Salemba Medika

Wahyuni, Nida Q. (2010). Pengaruh Senam Hamil Terhadap Perubahan Kadar Hemoglobin ( $\mathrm{Hb})$ Pada Kehamilan Trimester Ketiga. Jurnal Kesehatan, 3(2)

Whalley, Janet dkk. 2008.Kehamilan dan Persalinan.Jakarta: PT Bhuana Ilmu Populer.

WHO, (2013). Trend in Maternal Mortality 2013. www.who.int 